Extract from THE SOCIOLOGIGAL QUARTERLY Autumn, 1964

\title{
The Patrimonial Thesis and Pre-Modern Japanese Herrschaft
}

\author{
By \\ Norman Jacobs
}

East Asian Series, Reprint No. 1

CENTER FOR EAST ASIAN STUDIES

THE UNIVERSITY OF KANSAS

Lawrence, Kansas 


\section{The Patrimonial Thesis and Pre-Modern Japanese Herrschaft}

Norman G. Jacobs, University of Kansas 


\title{
The Patrimonial Thesis and Pre-Modern Japanese Herrschaft
}

\author{
Norman G. Jacobs, University of Kansas
}

I wISH to comment on that section of Professor Murvar's excellent paper which discusses the Weberian thesis that "traditional" Japanese Herrschaft, in common with the Herrschaft of "traditional" China, may be characterized as patrimonial-prebendary in spite of the existence of certain feudal features peculiar to the specific Japanese situation. ${ }^{1}$

This view of pre-industrial Japanese Herrschaft essentially is one that considers Japanese society as similar to the societies which arose in continental East Asia, with minor concessions granted to the uniqueness of all individual societies. I wish to dissent. I hasten to add immediately that I firmly believe that the patrimonial concept is useful, even essential, for an understanding of continental Asian societies, especially Chinese society, and hence, by developing the concept, Weber made a valuable contribution both to sociology and to the field of Asian studies. But, in converse to the specific Weberian thesis cited here, I would suggest that Japanese society, rather than being considered as patrimonial-prebendary, is better interpreted as feudal with the same essential structure as that of other feudal (especially western European) societies.

One of the paramount assumptions of Weber's two major works on Asian religion ${ }^{2}$ is that the religious systems of China and India must be treated as integral elements in respective social systems which are conceptualized as ideal-typical. The only variations over time which are significant are those which violate the logical limits of tolerance established by the range of concern of the ideal-typical system. The range of concern in the present discussion, of course, are those influences which pertain to patrimonialism versus feudalism. For example, in Chinese society, Weber would maintain that

${ }^{1}$ For further general discussion of the problem of feudalism in Jal. nese society, see R. Colbourn, Feudalism in History (Princeton, N.J., 1956), pp. 26-48, 188-214.

${ }^{2}$ The Religion of China (Glencoe, Ill., 1951); and The Religion of India (Chicago, 1958). 
the range of tolerance was exceeded at the changeover from a feudal to a patrimonial type of social organization about the year 200 B.C. $^{3}$ But, since subsequent changes in Chinese society, significant as they may be, did not alter the basic patrimonial-prebendary structure of Chinese Herrschaft, such changes are not of consequence for the problem at hand. If change in Chinese society is interpreted in this way, it is apparent that Weber did not consider Chinese (or any) society as being "static"; certainly even a superficial thumbing of his monograph on Chinese religion attests this. But it does suggest that, for certain theoretical purposes, it may be more useful to ignore certain kinds of change and emphasize certain kinds of consistency, in effect to conceptualize a society not as a singular moment in time, contemporary or historical, or as a series of discrete singular moments, but as an ideal-typical construct with certain select, consistent characteristics, irrespective of changes that may have taken place in that society over time. This view of course, does not preclude the possibility that these consistent characteristics may change, as highlighted by the preceding discussion of Chinese society.

This approach to the study of a society, like all sociological approaches, has as many problems as it has virtues. For one, it obviously enfuriates the chronologically conscious historian, and legitimately so-if one is interested in chronological development. Nevertheless, I do believe that this method is essential for certain sociological purposes, especially for the present problem of determining the nature of Japanese Herrschaft and its influence on the development of Japan in the last few centuries. For I would argue, first, that when certain characteristics in a society are selected to represent that society in the analysis of a theoretical problem such as the present one (a routine sociological procedure, to note), this method helps to insure that the selected traits are not atypical of the fundamental ideal-typical design. This consideration, I suggest, is important, especially if the entire context of the study is limited to only one historical moment, on grounds that this is the very time in which a particular social drama has or has not occurred. For I would argue that, especially in such a case, the method may provide a superior guide in the selection of those very characteristics which logically must be the measure of difference for determining why a particular event did or did not occur in that society.

\footnotetext{
${ }^{3}$ The Religion of China, Chapter II.
} 
Unfortunately neither Weber ${ }^{4}$ nor certain of his followers as, for example, Robert Bellah, ${ }^{5}$ in writing on Japanese religion and society, have followed this methodological design. Rather, they have concentrated almost exclusively on one period of Japanese history, namely, that period which covered the two and a half centuries immediately prior to the modern industrial era, termed the Tokugawa era. Logically, it cannot be denied that this period is crucial to the major problem raised by Weber, namely, the development of modern industrial capitalism in Japan, for no other reason than that the period immediately preceded the era of modern capitalism, and hence, whatever happened to bring about the establishment of modern capitalism must have happened in this period. Yet, I would suggest that this limited approach may not be the most rewarding means to explain the origins of modern capitalism in Japanese society. And I would suggest that it was this unusual approach to the Japanese case by Weber and his followers, perhaps out of a desire to demonstrate that self-generated modern industrial capitalism was unique to the West, that gave rise to the patrimonial-prebendary thesis. If one follows the guidelines of the India and China studies, taking into account the full sweep of Japanese pre-industrial society, I suggest (1) that the patrimonial features are atypical, while the feudal features are typical, of the fundamental assumptions of pre-industrial Japan viewed as an ideal-typical system, and (2) that it was the typical feudal and not the atypical patrimonial features that were the contributors to the success of the break-through of Tokugawa society and the establishment of modern industrial capitalism in Japan, which is compatible with Weber's general thesis of the origin of modern industrial capitalism.

\footnotetext{
${ }^{4}$ Weber never made a thorough study of the religious system of Japanese society comparable to his works on Chinese and Indian societies. This may very well be at the root of the present problem. Only scattered fragmentary observations on Japanese religion and society exist throughout his work, notably in his study of Herrschaft as discussed in Professor Murvar's paper. The nearest to a systematic essay of which I am aware is a short discussion, primarily of Buddhism, in the India volume, Colbourn, op. cit., pp. 270-82.

${ }^{5}$ To be sure, Bellah in Tokugawa Religion (Glencoe, Ill., 1957), p. 178, explicitly states that he wishes to limit the study of Japanese religion to one historical period, the Tokugawa era (1003-1868), which immediately preceded the initial period of the modern industrial era, the Meiji era (1868-1912); and certainly that is his privilege. But what are the necessary and sufficient conditions in Tokugawa society that explain the success of the subsequent industrial development of the Meiji era? Bellah and I disagree on these conditions, in part, I suggest, because of the difference in the time span we have chosen to serve as the model against which to select and interpret the universe of the empirical evidence.
} 
The second major methodological consideration which prompts me to suggest that Japanese Herrschaft should not be considered as patrimonial is that $\mathrm{I}$ believe it is important logically to differentiate between the concepts "cultural" and "social" as well as, within the concept "social," between "form" (or "structure") and "function." "I would say that all these distinctions are significant in the Japanese case, because I believe it is from the social-functional standpoint that Japanese society not only may very well be qualitatively different from patrimonial Chinese society but also that it may be similar to the feudal societies of western Europe. ${ }^{7}$ Consequently, although I freely concede that many of the formal features of Tokugawa Japan were similar to those of patrimonial China, this similarity does not necessarily imply that Japanese society, viewed as a dynamic functional system, was patrimonial nor, on that account, that Japanese society is to be differentiated qualitatively from the western European feudal societies. ${ }^{8}$

Within these basic methodological guidelines I would interpret the nature of Japanese, especially Tokugawa, Herrschaft and society as follows: ${ }^{9}$

1. In accord with the fundamental assumptions of Japanese Herrschaft accepted since the seventh century, the Tokugawa, as its predecessors, legitimized its general right to that Herrschaft on the

${ }^{6}$ I would define the "cultural" as the patterned products of man, material and nonmaterial; in the present discussion, the nonmaterial, or symbolic, aspect is prime. In contrast, the "social" may be defined as the relationships between human beings. The distinction, to be sure, is logical, and since both the cultural and the social are constructs derived from human behavior, they may very well be interrelated in any particular study. But in the present instance, for reasons to be discussed subsequently, I am arguing that they need not be interrelated. Conceptualized on a very general level, which I trust will avoid controversy, "form" may be defined as answer to the question, "How does it look?" and "function" as answer to the question, "How does it work?" Again the two constructs may be interrelated in any analysis, but they need not be, and I wish to argue that, in the case presently under discussion, they are not.

'I have argued this in greater detail in my Origin of Modern Capitalism and Eastern Asia (Hong Kong, 1958).

${ }^{8} \mathrm{John}$ W. Hall, as cited in Murvar's paper, has argued for the uniqueness of Japanese feudalism. Certainly this is important for understanding the singular nature of Japanese society and the particular path which it has taken in the development of modern capitalism, and I do not wish to minimize that uniqueness. But at the same time I must argue that this approach very well might obscure what I believe are important distinctions and similarities on a more general level of analysis.

9 Detailed documentation for the following discussion may be found in any standard history of Japan, as for example, J. Murdoch's three volumed History of Japan, many editions, and the recent G. Sansom's three volumed History of Japan (Stanford, Calif., 1961-63). For a more detailed treatment of my theoretical view of the historical material, see Jacobs, op. cit. 
basis of an empirical demonstration of superior coordinative skill and military power as against all rival claimants. The Tokugawa legitimized its right to establish and maintain the specific Herrschaft that it formulated by demonstrating, in contrast to all potential rivals, an empirical ability to solve the existing specific problem of order as defined functionally at the specific historical moment when the Tokugawa rose to power. At the beginning of the seventeenth century, superior political ability implied the ability to establish a peaceful, unified order to replace the chaotic decentralized feudalism which had prevailed through most of the previous centuries. This is to be contrasted with the fundamental assumptions of a patrimonial Herrschaft (as, for example, pre-modern Chinese Herrschaft) which consists of a constant structure, defined and legitimized by a moral, charismatic political elite dispensing or withdrawing political favors on grace without review to those of more limited political morality.

2. Yet, in spite of this contrast of fundamental assumptions between Chinese and Japanese Herrschaft, it cannot be denied that many of the specific cultural and social forms of Tokugawa social order resembled those of seventeenth century China because they were consciously borrowed or adapted from them. Why then did Tokugawa Japan, if it was feudal, not look to the Herrschaft of the European nation-states as the source or inspiration for its proposed solution to the problem of political order? Perhaps, it might be argued, at least Tokugawa Herrschaft, if not Japanese Herrschaft in general, was patrimonial? I would suggest that although the features of the developed feudalism and rising national states of the West were known to the Japanese, and although certain features of European culture and society prompted admiration in certain Japanese quarters, the late sixteenth-century political experience of the Japanese with the Europeans was not such as to encourage emulation as far as statecraft was concerned. On the other hand, because of continued contact over a millennium characterized by extensive social and cultural borrowing, China represented the known and the acceptable to the Japanese, especially in an age when the freebooting West had yet to validate its claim to alleged superiority over the social orders of East Asia. But the Tokugawa adoption of Chinese social and cultural forms did not necessarily imply the adoption of the functions associated with these forms in the Chinese system, especially not the fundamental assumptions associated with 
patrimonial-prebendarism. I would suggest further that this adoption of forms but not of functions has been the pattern of Japanese borrowing from China since the seventh century and is one of the cardinal, constant measures of difference between the two societies, regardless of any apparent similarity in certain social and cultural forms. ${ }^{10}$

3. Consequently, I suggest that whatever Chinese forms were introduced into Japanese society, they were legitimized and enforced, not on the basis of the charismatic assumptions of the Chinese patrimonial system of Herrschaft, but on the basis of the pragmatic assumptions of Japanese feudal Herrschaft. Apparently, because of the fundamental non-patrimonial assumptions of Japanese society, it was never in a position to institutionalize those functions of Herrschaft which were associated with the qualitatively alien system of patrimonial Chinese society. This principle was established in the seventh century, and seventeenth-century Japan was not different in this respect. ${ }^{11}$

Hence, although the Tokugawa made a valiant attempt to introduce many formal features of a patrimonial-prebendary society, it never succeeded (any more than did any of its predecessors who attempted it) in introducing patrimonialism as a functional system into Japanese society, only, I suggest, the skeletal forms of that system. Consequently, I conclude that the forms of patrimonial prebendarism that were legitimized, were established and maintained, not on the basis of the Chinese moral right, but upon the basis of the Japanese assumption of an empirically demonstrated ability to do so, specifically on the grounds that, in contrast to rival claimants, the forms were integral elements of the superior solution to the problem of unitary order proposed by the Tokugawa at the time it came into power. When in the middle of the nineteenth century it became obvious that the Tokugawa no longer was able to justify its alleged superiority in solving the problem of Herrschaft and order, and when a novel, and apparently more efficacious Herrschaft was proposed-importantly, in response to the dramatically altered functional demands of mid-nineteenth century Japanese society-the legitimate right to hold the mantle of Herrschaft passed from the Tokugawa to a new claimant, the Royalists, who, consis-

\footnotetext{
${ }^{10}$ For a detailed account of this significant characteristic in the case or Japan's first major borrowing from China in the seventh century, see K. Asakawa, The Early Institutional Life of Japan (Tokyo, 1903).

${ }^{11}$ Ibid., especially pp. 333-46.
} 
tent with the Japanese fundamental assumptions of Herrschaft, empirically demonstrated an ability to respond more successfully to the challenge of the new industrial era then dawning in Japan. And at this time, although once again many forms of Chinese society persisted and even new ones were introduced, Japanese society now was ready to accept what the West had to offer in form as well as in function.

4. Account of the origin and development of the particular Herrschaft that destroyed the Tokugawa is of prime interest to the present discussion. From the very beginning of the establishment of the Tokugawa ascendancy, in spite of the conscious adoption of many formal features of the Chinese patrimonial system which was designed in the hopes of relieving the pressure, the Tokugawa was forced (once again, I would say, by the functional demands of the fundamental assumptions of Japanese society) to acknowledge the legitimacy of independent rights and privileges among centers of decentralized authority outside its direct control, and even to recognize reciprocal rights, privileges, and obligations within its own domain. This concept of Herrschaft is a familiar feature of feudalism and may be contrasted with the localized, often illegitimate arrogation of authority characteristic of patrimonial prebendarism.

Certainly, in the early days of the Tokugawa, these decentralized centers were weak as against the Tokugawa might, but because of the recognition of the legitimacy of decentralized rights and privileges, albeit limited, these centers were potentially capable of developing significant countervailing authority. And, historically speaking, this is precisely what happened in the eighteenth and especially in the nineteenth century (as it, for the same reason, had happened again and again previously in Japanese society between a titular central authority and localized authority). This localized authority, especially the so-called "outside clans," 12 increasingly evaded the pseudo-patrimonial agricultural taxation and commercial restrictive policies of the Tokugawa as it became evident that the Tokugawa, because of the Japanese fundamental assumptions of Herrschaft as an empirical test of coordinative and military superiority, was growing steadily weaker and, hence, was unable to enforce its political decisions. And it was these outside centers of authority which spearheaded the overturn of the Toku-

${ }^{12}$ The "tozama" clans; see A. M. Craig, Choshu in the Meiji Restoration (Cambridge, 1961), pp. 350-74. 
gawa Herrschaft, significantly along with the specific Tokugawa form of Herrschaft, replacing it with the industrial order of Meiji, an order more responsive to the functional demands of the new pragmatic situation. It is worth noting, in passing, that all this is in marked contrast to the fate of Chinese society in the same period, a society which, because of the fundamental assumptions of patrimonialism, was unable to respond as readily as Japan to the functional demands of the same order of industrial challenge. ${ }^{13}$

In conclusion, I would suggest that, certainly, it is ridiculous to deny that China always has had a profound effect on the forms of Japanese society and culture. But if one interprets the borrowing process from the functional point of view, I would suggest that the reverse of the Weberian thesis is valid, namely, that Japanese Herrschaft, from the seventh to the nineteenth century, may be characterized as feudal, in spite of the fact that certain formal similarities to Chinese Herrschaft existed. This discontinuity between formal similarity and functional dissimilarity to Chinese Herrschaft had made Japanese Herrschaft a significantly different member of the feudal ideal-typical system but, I would claim, not a pariah of that system and certainly not a member of the patrimonial-prebendary ideal-typical system predominant in continental Asia. ${ }^{14}$

I hasten to add that this view in no way is meant to disparage the patrimonial-prebendary theory; quite the contrary. I believe that the concept is of inestimable value as, for example, in helping to explain the differential receptivity to modern industrial order between feudal Japan and patrimonial China. And so, once again, one is indebted to Max Weber for still another seminal insight which is of utmost importance, in this case to the field of Asian studies as well as to sociology-further testimony to Weber's genius and continuing value to present-day and future research.

${ }^{13}$ For a fuller discussion of this see Jacobs, op. cit.; S. Y. Teng, China's Response to the West (Cambridge, 1954), and A. Feuerwerker, China's Early Industrialization (Cambridge, 1958).

${ }^{14}$ I may cite K. A. Wittfogel's, Oriental Desnotism (New Haven. 1957) and the Japanese economist's, H. Otsuka's Kindai Shihonshugi No Keifu (The Pedigree of Japanese Capitalism, Tokyo, 1947), as but two examples of those influenced by the patrimonial-prebendary theory. 


\section{Notes and Commentaries}

\section{Ethical Neutrality and the Perspective of the Sociologist .}

THus is the centenary of the birth of Max Weber. It is slightly more than forty years since he died. His seminal insights still influence long after his death. It would perhaps not be inappropriate to consider, in the light of the present state of the discipline, a concern basic to the Weberian enterprise: the necessary Wertfreiheit of the man of knowledge.

As elaborated in "Wissenschaft als Beruf," ${ }^{1}$ Weber suggests that, for the sociologist, the classroom is not the place for polemics nor is the research undertaking a context for subjective meanderings. Like any professional, the sociologist is to be the "man who knows" -in this case about the dynamics of social conduct-and his talents and information are to be available, sine ire ac studio, to the person ready to use it in the service of good. But what good? Presumably, the welfare of man. But how or where is this to be defined? This Weber does not tell us.

Whether the sociologist likes it or not, whether he admits it or not, he operates within a context of values. The acquisition of knowledge is in itself a value, the canons by which such knowledge can be acquired and disseminated is still another, and, finally, that the sociologist should have no values is in itself a value. Needless to say, these values constitute a portion of the normative framework by whose mandate the sociologist operates. It was not always thus.

When Comte coined the term "sociology," he saw this domain not merely as a novel perspective in which to order knowledge about the human socius, but he saw sociology further as a tool through which humanity might be, as he saw it, relieved from the archaic prejudices and dogmas of outworn creeds, through which humanity might be seen as the creator, not merely the consumer, of ideologies (as, indeed, Bacon had argued three centuries earlier). That such a view of the field is now thoroughly discredited by sociologists does not invalidate the observation that sociology

${ }^{1}$ Max Weber, "Wissenschaft als Beruf," trans. "Science as a Vocation," in H. H. Gerth and C. Wright Mills (eds.), From Max Weber: Essays in Sociology (New York: Oxford Univ. Press, 1946), pp. 129-56. 